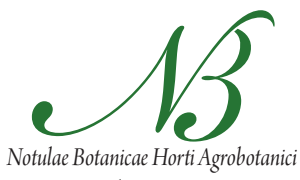

Cluj-Napoca

\title{
Cultivar Selection and Pest Control Techniques on Organic White Cabbage Yield
}

\author{
Vasile V.STOLERU*, Neculai C.MUNTEANU, Carmen Maria V.STOLERU, Liliana G. ROTARU \\ University of Agricultural Sciences and Veterinary Medicine, Department of Vegetable, Faculty of Horticulture, \\ 3 M. Sadoveanu street, 700490, Iasi, Romania; vstoleru@uaiasi.ro (" corresponding author)
}

\begin{abstract}
In Romania, as in many other countries, white cabbage is one of the most important vegetable crop species. The experiment was performed in the NE of the country during 2008-2009 in order to measure the impact of cultivar choice and pest control techniques on organic white cabbage [Brassica oleracea (L.) var. capitata f. alba (D.C.)]. This experiment included early, summer and autumn crops. The early crop compared four cultivars, the summer crop two cultivars, and the autumn crop three cultivars. The effect of various common organic pest control techniques was also measured. These techniques included: treatments with extract from neem (Azadirachta indica), potassium soap, Bacillus thuringiensis var. kurstaki toxins, application of a parasitic wasp (Trichogramma evanescens) and covering the crop with an agrotextile. Data were collected regarding the effect of cultivar selection and pest control technique on common local cabbage pests: cabbage flea beetle (Phyllotreta atra), cabbage fly (Delia brassicae), cabbage moth (Mamestra brassicae) and cabbage butterfly (Pieris brassicae). The highest yields for each respective growing season were obtained using the following combinations: 'Flavius' $\times$ agrotextile (early crop), 'Copenhagen Market' $\times$ agrotextile $+41 \cdot \mathrm{ha}^{-1}$ azadirachtin $+12 \cdot 10^{4}$ wasps/ha (summer crop) and 'Buzau' $\times 4$ l.ha' ${ }^{-1}$ azadirachtin (autumn crop).
\end{abstract}

Keywords: biological control, Brassica oleracea, cabbage pests, ecological crop production, varieties

\section{Introduction}

The main goals of organic farming are the preservation of agricultural ecosystems and the sustainable production of healthy products for consumers. These goals are achieved through natural environmental conditions and applied cultural practices (Munteanu et al., 2008).

White cabbage is an important organic crop in Romania. Field cultivation of organic white cabbage depends heavily on a series of properly applied cultural practices, including the choice of land (Pfiffner et al., 2009), crop rotation (Stoian, 2005), cultivar selection (Greenland et al., 2000), manure and fertilizer application (Stoleru and Imre, 2007), and weed, pest and disease control (Bianchi et al., 2005, Fatouros and Huigens, 2012, Furlong et al., 2008, Pfiffner $e t$ al., 2009). In addition to producing highquality crops, healthy, well-balanced soil can help plants develop natural resistance to both insect and disease pests (Blake, 1999).

As in many countries, Romania aims to reduce the use of synthetic chemical pesticides, and in this sense, the approach is beneficial to organic systems, which favors maintaining the natural balance between pests and the useful fauna (Stoian, 2005).

To choose the appropriate cultivar, several criteria were taken into account: the climate and soil conditions, crop system, product destination, time of sowing, planting and harvesting period, resistance to diseases and pests (Bajwa and Kogan, 2002; Mitchell et al., 2011; Munteanu et al., 2008), adaptation to extreme environmental conditions, photoperiod length, the overall cost of fertilizers, and consumer preferences.

Spores and crystalline insecticidal proteins produced by $B$. $t$. var. kurstaki have been used to control insect pests since the 1920s. They are now used as insecticides under trade names such as Dipel and Thuricide. Because of their specificity, these pesticides are regarded as environmentally friendly, with little or no effect on humans, wildlife, pollinators, and most other beneficial insects (Höfte et al., 1986). T. evanescens are facultatively gregarious, polyphagous egg parasitoids that are often used in inundative biological control programs against a wide range of lepidopterous eggs (Smith, 1996).

Prior research on cabbage pests has shown several things. First, early cabbage was attacked less frequently by the cabbage moth, especially $1^{\text {st }}$ and $2^{\text {nd }}$ instar-staged larvae. This resulted in production losses of approximately $0.7 \%$ of the total production. For late cabbage, insect damage during the heading stage caused $9.8 \%$ to $11.2 \%$ losses in production. Finally, the cabbage flea may cause damage of up to $35 \%$ of the final harvest, and is especially destructive during the seedling stage (Calin, 1996).The most harmful pests for white cabbage in northeastern Romania (Georgescu, 2006) are listed below, by growing season: 
(a) for early crops - cabbage aphid (Brevicoryne brassicae), cabbage fly and cabbage moth; moth;

(b) for summer crops - cabbage aphid and cabbage

(c) for autumn crops - cabbage aphid, cabbage moth and cabbage butterfly.

The purpose of this experiment was to study the influence of both cultivar selection and pest control techniques on the degree of pest attack, and on the total yield of white cabbage. These measures were applied to three growing seasons: early, summer and autumn.

\section{Materials and methods}

\section{Site description}

The bifactorial experiment was carried out at the University of Agricultural Sciences and Veterinary Medicine, Iasi, in an organic certified horticultural farm. The farm is located in northeast of Iasi (lat. $47^{\circ} 10^{\prime} \mathrm{N}$ and long. $27^{\circ} 30^{\prime}$ $\mathrm{E}$. The local climate is characterized by an average annual temperature of $9.6^{\circ} \mathrm{C}\left(49.3^{\circ} \mathrm{F}\right)$ and a total average rainfall of $521 \mathrm{~mm} \cdot \mathrm{year}^{-1}$. In terms of the morphological and systematic soil conditions, the soil is classified as chernozem $(\mathrm{Cz})$ formed on mold (Filipov, 2005).

The crops were established using seedlings that were produced in the farm greenhouses in cellular trays $4 \times 4$ $\mathrm{cm}$ for the early and summer crops, and $3 \times 3 \mathrm{~cm}$ for the autumn crop, according to European Council Regulations 834/2007. Plug-tray transplants showed the greatest increase in leaf area following transplanting and matured earlier than seedlings produced in other systems (Frantz et al., 1999). The experimental crops were grown according to standards set forth in the scientific literature (Guerena, 2006; Stan and Munteanu, 2001).

\section{Experimental field}

Each crop was established on level ground using drip irrigation, and well-balanced crop rotation. Each autumn, the soil was fertilized using $25 \mathrm{t}$.ha ${ }^{-1}$ of mature chicken compost, and plowed to a depth of $28-30 \mathrm{~cm}$. Each crop was established by transplanting at different times: 15-20 Apr. for the early crop, 15-20 May for the summer crop and 15-20 June for the autumn crop.

Two experimental factors were studied, the first factor was the cultivar and second factor was the pest control technique. The cultivars used were well known and suitable for Romania, having originated either in Romania or in other European countries. The pest control measures consisted of various techniques, all of which are commonly used in organic horticulture (Munteanu et al., 2008). The following pest control measures were used: application of extract from neem (azadirachtin - active substance), agrotextile non-woven material to cover the crop (Agril P17, Fiberweb, Biesheim, France); potassium soap - a plant non-toxic soap based on potassium hydroxide; $B$. $t$. var. kurstaki toxins and application of parasitic wasps .
The first experimental factor was the cultivars. The names of the four cultivars used for the early crop were 'Timpurie de Vidra,' 'Ditmark,' 'Golden Acre' and 'Flavius'. The summer crop used cultivars 'Gloria' and 'Copenhagen Market'. The autumn crop cultivars were 'Buzau', 'Braunschweig' and 'Licurisca'.

The second experimental factor was the pest control technique utilized. The three techniques used for the early crop were: $4 \mathrm{l}^{\mathrm{h}} \mathrm{ha}^{-1}$ azadirachtin, agrotextile coverage, or 4 l.ha ${ }^{-1}$ azadirachtin $+201 \cdot h^{-1}$ potassium soap. Likewise, the summer crop received one of the following three treatments: 4 l.ha ${ }^{-1}$ azadirachtin + one application of $12 \cdot 10^{4}$ wasps/ha, agrotextile coverage $+4 \mathrm{l} \cdot \mathrm{ha}^{-1}$ azadirachtin + one application of $12 \cdot 10^{4} \mathrm{wasps} / \mathrm{ha}$, or $41 \cdot \mathrm{ha}^{-1}$ azadirachtin +20 l.ha ${ }^{-1}$ potassium soap + one application of $12 \cdot 10^{4}$ wasps/ha. Lastly, the autumn crop was treated using one of the following three techniques: $51 \cdot \mathrm{ha}^{-1}$ azadirachtin, 1.5 $\mathrm{kg} \cdot \mathrm{ha}^{-1}$ B. t. var. kurstaki toxins, or three applications of $12 \cdot 10^{4} \mathrm{wasps} / \mathrm{ha}$.

The observations and measurements regarding the influence of the cultivar selection and pest control techniques were made at the heading phase and at harvest for the early crop, at the rosette and heading phases for the summer crop and after planting, in the rosette and in the heading phases for the autumn crop. Most of the insect damage to the cabbage was assessed according to the degree of attack. The biological control used for cabbage moth assessed using method recommended (Parepa et al., 2006). The crops were harvested manually at the optimum harvest time for each of the cultivars. The early cabbage was harvested in June and July, the summer crop in August and the autumn crop in October.

\section{Data analysis}

The experimental data were assessed according to technical standards commonly applied to polyfactorial experiments. The experimental data were compared using percentages and differences. The influence of the experimental factors was estimated by the variance analysis (ANOVA) method, using the Fisher test (ratio of error of variance and treatment variance). The significance of the differences was assessed by taking into account the lowest significant difference (LSD) for three degrees of confidence: 95\%, 99\% and 99.9\% (Jitareanu, 1994; Saulescu and Saulescu, 1967).

\section{Results and discussion}

The efficacy of various combinations of cultivar and pest control combinations on the early cabbage crop is shown in Tab. 1 . The degree of attack of the cabbage aphid on the early crop ranged from $0.8 \%$ for 'Flavius' with agrotextile, up to $1.7 \%$ for 'Ditmark' with $41 . \mathrm{ha}^{-1}$ azadirachtin.

Crop cover can be used to provide effective protection against pests and other. The nonwoven structure provides 
192

Tab 1. Efficacy of cultivar x pest control measures on early organic cabbage (2008-2009)

\begin{tabular}{|c|c|c|c|c|c|c|c|c|c|}
\hline \multirow{2}{*}{ Treatment $^{\mathrm{z}}$} & \multirow{2}{*}{$\begin{array}{l}\text { Cabbage } \\
\text { phenophase }\end{array}$} & \multicolumn{2}{|c|}{$\begin{array}{c}\text { Damage by } \\
\text { cabbage fleas }\end{array}$} & \multicolumn{2}{|c|}{ Damage by cabbage fly } & \multicolumn{2}{|c|}{$\begin{array}{c}\text { Damage by } \\
\text { cabbage moth }\end{array}$} & \multicolumn{2}{|c|}{ Total yield $^{x}$} \\
\hline & & $\begin{array}{c}\text { Adults } \\
\text { (no./plant) }\end{array}$ & $\mathrm{DA}(\%)^{\mathrm{y}}$ & $\begin{array}{c}\text { Larvae } \\
\text { (no./ plant) }\end{array}$ & $\mathrm{DA}(\%)^{\mathrm{y}}$ & $\begin{array}{c}\text { Larvae } \\
\text { (no./ plant) }\end{array}$ & $\mathrm{DA}(\%)^{\mathrm{y}}$ & $\left(\mathrm{t} \bullet \mathrm{ha}^{-1}\right)$ & $\begin{array}{c}\text { Difference to } \\
\text { average }\left(\mathrm{t} \bullet \mathrm{ha}^{-1}\right)^{\mathrm{w}}\end{array}$ \\
\hline$a_{1} b_{1}$ & heading & 55.2 & 1.5 & $6-7$ & 8.5 & - & - & \multirow{2}{*}{23.97} & \multirow{2}{*}{$-2.79^{\circ 00}$} \\
\hline$a_{1} b_{1}$ & harvest & - & - & - & - & $2-3$ & 0.5 & & \\
\hline$a_{1} b_{2}$ & heading & 25.1 & 1.1 & $5-6$ & 8.9 & - & - & \multirow{2}{*}{26.07} & \multirow{2}{*}{$-0.69^{\mathrm{NS}}$} \\
\hline$a_{1} b_{2}$ & harvest & - & - & - & - & $1-2$ & 0.3 & & \\
\hline$a_{1} b_{3}$ & heading & 39.4 & 1.3 & $7-8$ & 10.2 & - & - & \multirow{2}{*}{25.23} & \multirow{2}{*}{$-1.53^{\circ}$} \\
\hline$a_{1} b_{3}$ & harvest & - & - & - & - & $1-2$ & 0.4 & & \\
\hline$a_{2} b_{1}$ & heading & 57.1 & 1.7 & $7-8$ & 13.2 & - & - & \multirow{2}{*}{22.07} & \multirow{2}{*}{$-4.69^{\circ 00}$} \\
\hline$a_{2} b_{1}$ & harvest & - & - & - & - & $1-2$ & 0.6 & & \\
\hline$a_{2} b_{2}$ & heading & 27.1 & 1.2 & $5-6$ & 8.6 & - & - & \multirow{2}{*}{24.57} & \multirow{2}{*}{$-2.19^{\circ \circ}$} \\
\hline$a_{2} b_{2}$ & harvest & - & - & - & - & $1-2$ & 0.3 & & \\
\hline$a_{2} b_{3}$ & heading & 36.4 & 1.4 & $6-7$ & 9.4 & - & - & \multirow{2}{*}{23.33} & \multirow{2}{*}{$-3.43^{\circ 00}$} \\
\hline $\mathrm{a}_{2} \mathrm{~b}_{3}$ & harvest & - & - & - & - & $2-3$ & 0.4 & & \\
\hline$a_{3} b_{1}$ & heading & 41.9 & 1.3 & $10-11$ & 14.2 & - & - & \multirow{2}{*}{26.00} & \multirow{2}{*}{$-0.76^{\mathrm{NS}}$} \\
\hline$a_{3} b_{1}$ & harvest & - & - & - & - & $2-3$ & 0.6 & & \\
\hline$a_{3} b_{2}$ & heading & 20.1 & 1.1 & $5-6$ & 6.9 & - & - & \multirow{2}{*}{29.00} & \multirow{2}{*}{$2.24^{\circ}$} \\
\hline$a_{3} b_{2}$ & harvest & - & - & - & - & $1-2$ & 0.4 & & \\
\hline$a_{3} b_{3}$ & heading & 28.6 & 1.3 & $8-9$ & 10.3 & - & - & \multirow{2}{*}{27.10} & \multirow{2}{*}{$0.34^{\mathrm{NS}}$} \\
\hline$a_{3} b_{3}$ & harvest & - & - & - & - & $1-2$ & 0.5 & & \\
\hline$a_{4} b_{1}$ & heading & 36.7 & 1.2 & $8-9$ & 12.4 & - & - & \multirow{2}{*}{30.10} & \multirow{2}{*}{$3.34^{\cdots}$} \\
\hline$a_{4} b_{1}$ & harvest & - & - & - & - & $1-2$ & 0.4 & & \\
\hline$a_{4} b_{2}$ & heading & 21.6 & 0.8 & $6-7$ & 7.8 & - & - & \multirow{2}{*}{32.57} & \multirow{2}{*}{$5.81^{\cdots}$} \\
\hline$a_{4} b_{2}$ & harvest & - & - & - & - & $1-2$ & 0.3 & & \\
\hline$a_{4} b_{3}$ & heading & 26.4 & 1.2 & $9-10$ & 14.5 & - & - & \multirow{2}{*}{31.07} & \multirow{2}{*}{$4.31^{\cdots}$} \\
\hline$a_{4} b_{3}$ & harvest & - & - & - & - & $1-2$ & 0.4 & & \\
\hline$\overline{\mathrm{X}}$ & - & - & - & - & - & - & - & 26.76 & 0.00 \\
\hline
\end{tabular}

${ }^{2}$ Interaction cultivar and pest control management ( $a_{1}$ - 'Timpurie de Vidra'; $a_{2}$-'Ditmark'; $a_{3}$-'Golden Acre'; $a_{4}$-'Flavius'; $b_{1}$ - 4 l.ha ${ }^{-1}$ azadirachtin; $b_{2}$ - agrotextile (Agryl $\mathrm{P}_{17}$ - non-woven material, made by Fiberweb France < www.fiberweb.com >); $\mathrm{b}_{3}-4$ l.ha $\mathrm{h}^{-1}$ azadirachtin +20 l.ha ${ }^{-1}$ potassium soap);

${ }^{y}$ Degree of attack (DA) is equal to the product of frequency and intensity of attack: DA $=(\mathrm{FxI}) / 100$. Attack frequency (F\%) which is the ratio between the number of plants or plant organ attacked $(\mathrm{n})$ and total $(\mathrm{N})$ of plants or plant organ observed and calculated as: F\% $=\mathrm{n} / \mathrm{N}$ x 100 . The intensity of attack $(\mathrm{I} \%)$ expresses the percentage of plants, foliage or other plant organs damaged by pests;

'Total yield as average during 2008-2009, made at consumption maturity, 65 days after planting;

"Significance of differences made by ANOVA (analysis of variance) for experimental factors and interaction of them;

NS,${ }^{* * * * * *}$ - indicate nonsignificant and positive significant at $p \leq 0.05,0.01,0.001$, respectively;

o,oo,ooo - negative significant at $p \leq 0.05,0.01,0.001$, respectively

a physical barrier to insects (Erzsebet et al., 2007; Gerst, 1993; Walker, 2005).

Cabbage fly had a degree of attack ranging from $7.8 \%$ for 'Flavius' with agrotextile, up to $14.5 \%$ for 'Flavius' with $41 \cdot \mathrm{ha}^{-1}$ azadirachtin $+201 \cdot \mathrm{ha}^{-1}$ potassium soap. The degree of attack of the cabbage moth ranged from $0.3 \%$ for ' $\mathrm{Fla}$ vius', 'Timpurie de Vidra' and 'Ditmark', with agrotextile, up to $0.6 \%$ for 'Ditmark' and 'Golden Acre' with 4 l.ha ${ }^{-1}$ azadirachtin. The damage of the cabbage moth was determined at the larval stage during the harvesting phenophase of the early crop.

The effects of the different factor combinations on total yield are summarized in Tab. 1, with significant differences noted. The total yield varied from $22.07 \mathrm{t} \cdot \mathrm{ha}^{-1}$ for 'Ditmark' with $41 \cdot$ ha $^{-1}$ azadirachtin, up to $32.57 \mathrm{t} \cdot \mathrm{ha}^{-1}$ for 'Flavius', with agrotextile as the pest control. The produc- tion differences compared to the average (mean) yield ranged from $-4.69 \mathrm{t} \cdot \mathrm{ha}^{-1}$ ('Ditmark' $\times 4 \mathrm{l} \cdot \mathrm{ha}^{-1}$ azadirachtin) to 5.81 t.ha $^{-1}$ ('Flavius' $\times$ agrotextile).

Thus, the results obtained by using agrotextile are similar to results obtained by other authors (Erzsebet et al., 2006, 2007; Erzsebet, 2009; Karkanis et al., 2011). Aphids do not damage the crop before hearting. As pests may distort the heart, it is important to reduce their population as hearting commences and to remove them totally during hearting (Apahidean et al., 2004; Calin, 1996).

Seljasen and Meadow (2006), reveal that the application of azadirachtin in the larval stage 1 , occurs in cabbage fly and cabbage moth a high mortality.

Organic production obtained in early cabbage are reduced by $40-44 \%$ compared to the conventional system, 
even if the agryl protection (Erzsbet, 2009; Posta and Berar, 2007).

Most of the insect damage to the summer cabbage crop was assessed according to the degree of attack that the fleas and moths inflicted (Tab. 2). The degree of attack of the cabbage aphids on the summer cabbage crops ranged from 7.2\% for 'Copenhagen Market' with agrotextile, up to $13.7 \%$ for 'Gloria, with $4 \cdot 10^{-3}$ Azadirachtin applied during the rosette stage. Attack of the cabbage moth was determined in the larval stage, during the rosette and heading phenophases. The degree of attack during the rosette phenophase ranged from 6.8\% for 'Copenhagen Market' with agrotextile $+41 \cdot$ ha $^{-1}$ azadirachtin + one application of $12 \cdot 10^{4}$ wasps/ha, up to $12.3 \%$ for 'Gloria', to which $41 \cdot \mathrm{ha}^{-1}$ azadirachtin + one application of $12 \cdot 10^{4}$ wasps/ha was applied. The degree of attack during the heading phenophase was between $8.7 \%$ for 'Copenhagen Market' with agrotextile $+41 \cdot \mathrm{ha}^{-1}$ azadirachtin + one application of $12 \cdot 10^{4}$ wasps/ha, up to $15.1 \%$ for 'Gloria' with $41 \cdot$ ha $^{-1}$ azadirachtin $+20 \mathrm{l} \cdot \mathrm{ha}^{-1}$ potassium soap $+12 \cdot 10^{4}$ wasps $/$ ha.

On the summer cabbage crop, because planting was made a month later, there is a higher incidence of pest attack, which revealed a higher degree of attack, compared with early cabbage. Thus, besides the version that was used azadirachtin, Trichogramma evanescence and agryl degree of attack was reduced more than 50\%. Young plants are vulnerable to attack of cabbage fly at ground level, which means that agryl provides protection if installed before egg laying by the pest.
In the rosette stage, degree of attack is lower than phenophase formation of the head, which are similar to results of other authors (Bianchi et al., 2005; Seljasen and Meadow, 2006).

The effects of different factor combinations on total yield are summarized in Tab. 2. Distinctly significant differences were noted between many factor combinations. The total production varied from $32.13 \mathrm{t} \cdot \mathrm{ha}^{-1}$ for 'Gloria' with 4 l.ha ${ }^{-1}$ azadirachtin + one application of $12 \cdot 10^{4}$ wasps/ha, up to 37.83 t.hat ${ }^{-1}$ for 'Copenhagen Market' with agrotextile $+41 \cdot \mathrm{ha}^{-1}$ azadirachtin $+12 \cdot 10^{4}$ wasps $/$ ha

Most of the insect damage to the cabbage was assessed according to the degree of attack that was inflicted by cabbage aphids and moths (Tab. 3). The degree of attack of the cabbage aphids on the autumn crop ranged from 10.6 $\%$ for 'Licurisca' up to $12.4 \%$ for 'Braunschweig' to which 5 l.ha ${ }^{-1}$ azadirachtin was applied during the planting phenophase. During the rosette phenophase for the autumn crop, the cabbage fleas had a degree of attack ranging from $5.9 \%$ for 'Buzau' with $51 \cdot$ ha $^{-1}$ azadirachtin, up to $10.4 \%$ for 'Braunschweig' with $1.5 \mathrm{~kg} \cdot \mathrm{ha}^{-1}$ B. t. var. kurstaki toxins applied. The attack of cabbage moth was determined at the larval stage during the rosette and heading phenophases of the autumn crop. For the rosette phenophase, the degree of attack ranged from $5.6 \%$ for 'Licurisca'with three applications of $12 \cdot 10^{4}$ wasps/ha were used, up to $7.9 \%$ under the same protection measures. During the heading phenophase, the degree of attack was between 7.9\% for 'Buzau'

Tab 2. Efficacy of cultivar $x$ pest control measures on summer organic cabbage (2008-2009)

\begin{tabular}{|c|c|c|c|c|c|c|c|}
\hline \multirow[b]{2}{*}{ Treatment $^{z}$} & \multirow[b]{2}{*}{$\begin{array}{c}\text { Cabbage } \\
\text { phenophase }\end{array}$} & \multicolumn{2}{|c|}{ Damage by cabbage fleas } & \multicolumn{2}{|c|}{ Damage by cabbage moth } & \multicolumn{2}{|r|}{ Total yield $^{x}$} \\
\hline & & $\begin{array}{c}\text { Adults } \\
\text { (no./ plant) }\end{array}$ & $\mathrm{DA}(\%)^{\mathrm{y}}$ & $\begin{array}{c}\text { Adults } \\
\text { (no./ plant) }\end{array}$ & $\mathrm{DA}(\%)^{y}$ & $\left(\mathrm{t} \bullet h \mathrm{a}^{-1}\right)$ & $\begin{array}{l}\text { Difference to average } \\
\left(\mathrm{t} \mathrm{ha}^{-1}\right)^{\mathrm{w}}\end{array}$ \\
\hline$a_{1} b_{1}$ & rosette & $10-15$ & 13.7 & $4-5$ & 12.3 & \multirow{2}{*}{32.13} & \multirow{2}{*}{$-2.98^{\circ 00}$} \\
\hline$a_{1} b_{1}$ & heading & - & - & $4-5$ & 13.7 & & \\
\hline$a_{1} b_{2}$ & rosette & $5-10$ & 8.9 & $1-2$ & 8.9 & \multirow{2}{*}{34.00} & \multirow{2}{*}{$-1.11^{\mathrm{NS}}$} \\
\hline$a_{1} b_{2}$ & heading & - & - & $3-4$ & 11.2 & & \\
\hline$a_{1} b_{3}$ & rosette & $10-15$ & 12.8 & $2-3$ & 11.6 & \multirow{2}{*}{33.20} & \multirow{2}{*}{$-1.91^{\circ}$} \\
\hline$a_{1} b_{3}$ & heading & - & - & $4-5$ & 12.6 & & \\
\hline$a_{2} b_{1}$ & rosette & $5-10$ & 10.4 & $3-4$ & 9.6 & \multirow{2}{*}{37.50} & \multirow{2}{*}{$2.39^{\circ}$} \\
\hline$a_{2} b_{1}$ & heading & - & - & $4-5$ & 10.1 & & \\
\hline$a_{2} b_{2}$ & rosette & $4-8$ & 7.2 & $1-2$ & 6.8 & \multirow{2}{*}{37.83} & \multirow{2}{*}{$2.72^{*}$} \\
\hline$a_{2} b_{2}$ & heading & - & - & $3-4$ & 8.7 & & \\
\hline$a_{2} b_{3}$ & rosette & $8-10$ & 9.1 & $2-3$ & 10.4 & \multirow{2}{*}{36.00} & \multirow{2}{*}{$0.89^{\mathrm{NS}}$} \\
\hline$a_{2} b_{3}$ & heading & - & - & $4-5$ & 15.1 & & \\
\hline$\overline{\mathrm{X}}^{3}$ & - & - & - & - & - & 35.11 & 0.00 \\
\hline
\end{tabular}

${ }^{2}$ Interaction cultivar and pest control measure ( $a_{1}$ - 'Gloria'; $a_{2}$-'Copenhagen Market'; $b_{1}-41 \cdot h^{-1}$ azadirachtin + one application of $12 \cdot 10^{4}$ wasps $/$ ha; $b_{2}$ - agrotextile < Agryl $\mathrm{P}_{17}$ - non-woven material, made by Fiberweb France, www.fiberweb.com $>+41 \cdot \mathrm{ha}^{-1}$ azadirachtin + one application of $12 \cdot 10^{4}$ wasps $/$ ha; $^{\circ} \mathrm{b}_{3}-41 \cdot \mathrm{ha}^{-1}$ azadirachtin $+201 \cdot \mathrm{ha}^{-1}$ potassium soap + one application of $12 \cdot 10^{4}$ wasps/ha;

${ }^{y}$ Degree of attack (DA) is equal to the product of frequency and intensity of attack: DA $=(F x 1) / 100$. Attack frequency (F\%) which is the ratio between the number of plants or plant organ attacked $(\mathrm{n})$ and total $(\mathrm{N})$ of plants or plant organ observed and calculated as: F\% $=\mathrm{n} / \mathrm{N} \mathrm{x} 100$. The intensity of attack (I\%) expresses the percentage of plants, foliage or other plant organs damaged by pests;

'Total yield as average during 2008-2009, made at consumption maturity, 90 days after planting;

"Significance of differences made by ANOVA (analysis of variance) for experimental factors and interaction of them;

NS $, * * *, * * *$ indicate nonsignificant and positive significant at $p \leq 0.05,0.01,0.001$, respectively;

o,oo,ooo - negative significant at $p \leq 0.05,0.01,0.001$, respectively 
Tab 3. Efficacy of cultivar $\times$ pest control measures on autumn organic cabbage crop (2008-2009)

\begin{tabular}{|c|c|c|c|c|c|c|c|}
\hline \multirow[b]{2}{*}{ Treatment $^{2}$} & \multirow{2}{*}{$\begin{array}{l}\text { Cabbage } \\
\text { phenophase }\end{array}$} & \multicolumn{2}{|c|}{ Damage by cabbage fleas } & \multicolumn{2}{|c|}{ Damage by cabbage moth } & \multicolumn{2}{|r|}{ Total yield ${ }^{x}$} \\
\hline & & $\begin{array}{c}\text { Adults } \\
\text { (no./ plant) }\end{array}$ & $\mathrm{DA}(\%)^{\mathrm{y}}$ & $\begin{array}{c}\text { Larvae } \\
\text { (no./ plant) }\end{array}$ & $\mathrm{DA}(\%)^{\mathrm{y}}$ & $\left(\mathrm{t} \bullet h a^{-1}\right)$ & $\begin{array}{c}\text { Difference to average } \\
\left(\mathrm{t} \mathrm{ha}^{-1}\right)^{\mathrm{w}}\end{array}$ \\
\hline$a_{1} b_{1}$ & after planting & $1-2$ & 11.9 & - & - & & \\
\hline$a_{1} b_{1}$ & rosette & $4-8$ & 5.9 & $1-2$ & 6.4 & 54.47 & $6.38^{\cdots}$ \\
\hline$a_{1} b_{1}$ & heading & - & - & $3-4$ & 10.7 & & \\
\hline$a_{1} b_{2}$ & after planting & $1-2$ & 12.1 & - & - & & \\
\hline$a_{1} b_{2}$ & rosette & $5-9$ & 6.2 & $2-3$ & 7.9 & 51.23 & $3.14^{\cdots}$ \\
\hline$a_{1} b_{2}$ & heading & - & - & $4-5$ & 9.6 & & \\
\hline$a_{1} b_{3}$ & after planting & $2-3$ & 10.7 & - & - & & \\
\hline$a_{1} b_{3}$ & rosette & $6-10$ & 8.7 & $1-2$ & 5.8 & 52.90 & $4.81^{\cdots}$ \\
\hline$a_{1} b_{3}$ & heading & - & - & $4-5$ & 7.9 & & \\
\hline$a_{2} b_{1}$ & after planting & $1-2$ & 12.4 & - & - & & \\
\hline$a_{2} b_{1}$ & rosette & $4-5$ & 7.6 & $1-2$ & 6.4 & 47.73 & $-0.36^{\mathrm{NS}}$ \\
\hline$a_{2} b_{1}$ & heading & - & - & $3-4$ & 9.7 & & \\
\hline$a_{2} b_{2}$ & after planting & $7-8$ & 12.1 & - & - & & \\
\hline$a_{2} b_{2}$ & rosette & $5-9$ & 10.4 & $1-2$ & 7.1 & 46.50 & $-1.59^{\circ}$ \\
\hline$a_{2} b_{2}$ & heading & - & - & $5-6$ & 10.1 & & \\
\hline$a_{2} b_{3}$ & after planting & $3-4$ & 10.8 & - & - & & \\
\hline$a_{2} b_{3}$ & rosette & $7-10$ & 8.2 & $2-3$ & 6.8 & 46.13 & $-1.96^{\circ \circ}$ \\
\hline$a_{2} b_{3}$ & heading & & & $4-5$ & 9.5 & & \\
\hline$a_{3} b_{1}$ & after planting & $2-3$ & 10.6 & - & - & & \\
\hline$a_{3} b_{1}$ & rosette & 7.8 & 6.3 & $1-2$ & 6.8 & 45.73 & $-2.36^{\circ 00}$ \\
\hline$a_{3} b_{1}$ & heading & - & - & $3-4$ & 8.6 & & \\
\hline$a_{3} b_{2}$ & after planting & $2-3$ & 11.8 & - & - & & \\
\hline$a_{3} b_{2}$ & rosette & $10-12$ & 7.1 & $1-2$ & 7.3 & 43.60 & $-4.49^{\circ 00}$ \\
\hline$a_{3} b_{2}$ & heading & - & - & $3-4$ & 9.7 & & \\
\hline$a_{3} b_{3}$ & after planting & $3-4$ & 10.7 & - & - & & \\
\hline$a_{3} b_{3}$ & rosette & $10-15$ & 8.2 & $2-3$ & 5.6 & 44.53 & $-3.56^{000}$ \\
\hline$a_{3} b_{3}$ & heading & - & - & $3-4$ & 10.4 & & \\
\hline$\overline{\mathrm{X}}$ & - & - & - & - & - & 48.09 & 0.00 \\
\hline
\end{tabular}

${ }^{2}$ Interaction cultivar and pest control management ( $a_{1}$ - 'Buzau'; $a_{2}$-'Braunschweig'; $a_{3}$-'Licurisca'; $b_{1}-5$ l.ha ${ }^{-1}$ azadirachtin;

$\mathrm{b}_{2}-1.5 \mathrm{~kg} \cdot \mathrm{ha} \mathrm{I}^{-11}$ B. t. var. kurstaki toxins $<32.000$ U.I. $/ \mathrm{mg}>$; $\mathrm{b}_{3}$ - three applications of $12 \cdot 10^{4} \mathrm{wasps} / \mathrm{ha}$ );

${ }^{y}$ Degree of attack (DA) is equal to the product of frequency and intensity of attack: DA $=(\mathrm{FxI}) / 100$. Attack frequency $(\mathrm{F} \%)$ which is

the ratio between the number of plants or plant organ attacked $(n)$ and total $(\mathrm{N})$ of plants or plant organ observed and calculated as: F\%

$=\mathrm{n} / \mathrm{N} x$ 100. The intensity of attack (I\%) expresses the percentage of plants, foliage or other plant organs damaged by pests;

xTotal yield as average during 2008-2009, made at consumption maturity, 115 days after planting;

wSignificance of differences made by ANOVA (analysis of variance) for experimental factors and interaction of them;

NS,${ }^{* * * * * *}$ - indicate nonsignificant and positive significant at $p \leq 0.05,0.01,0.001$, respectively;

o,oo,ooo - negative significant at $p \leq 0.05,0.01,0.001$, respectively

with three applications of $12 \cdot 10^{4}$ wasps/ha applied, up to $10.7 \%$ for 'Buzau' with 5 l.ha ${ }^{-1}$ azadirachtin.

Can be noticed that the best results on pest control was achieved in variants treated with azadirachtin and those where wasps were applied. In variants where $B$. $t$. var. kurstaki was used, cabbage fly mortality was higher than $60 \%$, causing a degree of environmental attack, similar to other results obtained (Furlong et al., 2008), thus providing cost-effective production, but lower yield from 26.5 to 46\% (Apahidean et al., 2011; Furlong et al., 2008; Greenland et al., 2000).

The influence of the cultivar and pest control techniques on the total yield of the autumn crop is shown in the same table. ANOVA analysis confirms significant differences between the factor combinations. The total production varied from $43.60 \mathrm{t} \cdot \mathrm{ha}^{-1}$ for 'Licurisca' with $1.5 \mathrm{~kg} \cdot \mathrm{ha}^{-1}$ B. t. var. kurstaki toxins, up to $54.47 \mathrm{t} \cdot \mathrm{ha}^{-1}$ for 'Buzau' with 5 l.ha ${ }^{-1}$ azadirachtin used for pest control. Compared to the experimental mean, the yield differences ranged from -4.49 t.ha ${ }^{-1}$ ('Licurisca' $\times 1.5 \mathrm{~kg} \cdot \mathrm{ha}^{-1}$ B. t. var. kurstaki toxins) to 6.38 t.ha' ${ }^{-1}$ ('Buzau' $\times 5$ l.ha ${ }^{-1}$ azadirachtin). Distinctly significant positive differences were obtained when 'Buzau' was treated with $1.5 \mathrm{~kg} \cdot \mathrm{ha}^{-1}$ B. $t$. var. kurstaki toxins $\left(3.14 \mathrm{t} \cdot \mathrm{ha}^{-1}\right)+$ three applications of $12 \cdot 10^{4}$ wasps/ha $\left(4.81 \mathrm{t} \cdot \mathrm{ha}^{-1}\right)$. 


\section{Conclusions}

The highest level of the total production of the early crops was obtained in the case of the 'Flavius' F1 cultivar, when the covering system with Agryl $\mathrm{P}_{17}$ was used as a defense measure $(32.57 \mathrm{t} / \mathrm{ha})$.

The total production of the summer crop varied from $32.3 \mathrm{t} / \mathrm{ha}$ (in the case of the Gloria cultivar treated with $0.4 \%$ Neemazal T/S +1 application $\times$ Trichogramma evanescens at 120,000 individuals/ha) to $37.83 \mathrm{t} / \mathrm{ha}$ (in the case of the 'Copenhagen Market' cultivar treated with Agryl $+0.4 \%$ Neemazal T/S +1 application $\times$ Trichogramma evanescens at 120,000 individuals/ha).

The total yield for the autumn crop varied from 43.60 t/ha (in the case of the 'Licurisca' cultivar when $0.15 \% \mathrm{Di}$ pel was applied), to $54.47 \mathrm{t} / \mathrm{ha}$ (in the case of the 'Buzau' cultivar when $0.5 \%$ Neemazal T/S was applied.

\section{Acknowledgements}

This work was co-financed from the European Social Fund through Sectorial Operational Programme Human Resources Development 2007-2013, project number POSDRU / I 89 / 1.5 / S62371, Postdoctoral School in Agriculture and Veterinary Medicine area.

\section{References}

Apahidean AS, Apahidean M, Laczi E, Ivan I, Apahidean AI, Zagraian C (2011). Variety and plant density influence upon the yield of autumn white headed cabbage. Buletin USAMV Cluj-Napoca 68:527.

Apahidean AS, Apahidean M, Maniutiu D, Ganea R, Paven I, Ficior D (2004). The influence of plant protection on early cabbage cultivated in polyethylene film greenhouse. Not Bot Horti Agrobo 32:27-29.

Bajwa W, Kogan M (2002). Compendium of IPM Definitions (CID) - What is IPM and how is it defined in the Worldwide Literature? IPPC Publication no. 998, Oregon State University, Corvallis. OR 97331, USA.

Bianchi FJJA, van Wingerden WKRE, Griffioen AJ, van der Veen M, van der Straten MJJ, Wegman RMA, Meeuwsen HAM (2005). Landscape factors affecting the control of Mamestra brassicae by natural enemiesd in Brussels sprout. Agric Eco Env 107:145-150.

Blake F (1999). Organic farming and growing. The Crowood Press, Ramsbury.

Calin M (1996). Research biology and integrated pest management on cabbage. PhD thesis. USAMV Bucuresti, $115-173$ p.

Council Regulation (EC) (2007). No 834 of 28 June on organic production and labelling of organic products and repealing Regulation (EEC) No.2092/91 <http://eur-lex.europa.eu/ johtml.do?uri=OJ:L:2007: 189:SOM:en:HTML>

Erzsebet C (2009). Research concerning the possibilities to increase the early cabbage yield, in Transilvania specific conditions. Abstract of $\mathrm{PhD}$ thesis. USAMV Cluj-Napoca, 37-49 p.

ErzsebetC,Apahidean AS, Apahidean M,Buta M(2007). Studies concerning the influence of environmental conditions and protecting method on early cabbage production cultivated in open field. Buletin USAMV Cluj-Napoca 64:337.

Erzsebet C, Apahidean AS, Apahidean M, Cenariu D, Singureanu V, Moldovan G, Buta M (2006). The influence of plant protection on early cabbage cultivated in polyethylene film greenhouse. Buletin USAMV-Cluj-Napoca 63:385388.

Fatouros N, Huigens M (2012). Phoresy in the field: natural occurrence of Trichogramma egg parasitoids on butterflies and moths. BioControl 57:493-502.

Filipov F (2005). Soil sciences. Ed. "Ion Ionescu de la Brad” Iasi, $421-426 \mathrm{p}$.

FrantzJ, Welbaum G, Zhengxing S, Morse R(1999). Comparison of cabbage seedling growth in four transplant production systems. HortTech 9:128-133.

Furlong MJ, Kim Hak J, Pak Wi S, Jo Kwang C, Ri Chang I, Zalucki MP (2008). Integration of endemic natural enemies and Bacillus thuringiensis to manage insect pests of Brassica crops in North Korea. Agric Eco Env 125:223-238.

Georgescu T (2006). Horticultural entomology. Ed. Dosoftei, Iasi, 203-226 p.

Gerst JJ (1993). Legumes sous baches, guide practique. CTIFL, Paris, 198-217 p.

Greenland R, Lee C, Holm E, Besemann L (2000). Cabbage hybrid trials in North Dakota. HortTech 10:806-812.

Guerena M (2006). Cole crops and other brassicas: organic production. ATTRA.ORG.

Höfte H, H de Greve, Seurinck J (1986). Structural and functional analysis of a cloned delta endotoxin of Bacillus thuringiensis berliner 1715. Eur J Biochem 161(2):273-280.

Jitareanu G (1994). Experimental techniques. University of Agricultural Sciences, Iasi.

Karkanis A, Bilalis D, Efthimiadoy Aspasia, Savvas D, Konstantas A (2011). Effects of plant density and row arrangement on weed management and yield in organic cabbage crop (Brassica oleracea var. capitata L.). Buletin USAMV ClujNapoca 68:238-243.

Mitchell ER, Guangye H, Denise J (2011). Management of Diamondback moth (Lepidoptera: Plutellidae) in cabbage using collard as a trap crop. HortTech 11:150-151.

Munteanu N, Stoian L, Stoleru V, Falticeanu M (2008). Technological bases of organic vegetable. Ed. "Ion Ionescu de la Brad" Iasi, 62-127 p.

Parepa M, Diaconu A, Closca C (2006). Quality assessment for Trichogramma sp. strains used in biological control of pests from horticultural ecosystems. Sci Res Hort ISSN 14547376.

Pfiffner L, Luka H, Schlatter C, Juen A, Traugott M (2009). Impact of wildflower strips on biological control of cabbage 
196 lepidopterans. Agric Eco Env 129:310-314.

Posta G, Berar V (2007). Researches concerning the yield performances of the early cabbage hybrids cultivated in the field conditions. Buletin USAMV-Cluj-Napoca 64:113117.

Saulescu NA, Saulescu NN (1967). Field experiences. Ed. AgroSilvică, Bucuresti.

Seljasen R, Meadow R (2006). Effects of neem on oviposition and egg and larval development of Mamestra brassicae $\mathrm{L}$ : Dose response, residual activity, repellent effect and systemic activity in cabbage plants. Crop Prot 25:338-345.
Smith SM (1996). Biological control with Trichogramma: Advances, successes, and potential of their use. Annu Rev Entomol 41:375-406.

Stan N, Munteanu N (2001). Vegetable growing, vol. II. Ed. "Ion Ionescu de la Brad" Iasi, 115-138 p.

Stoian L (2005). Practical guide for organic vegetables. Ed. Tipoactiv, Bacau, 239-247 p.

Stoleru V, Imre A (2007). Growing vegetables by organic methods. Ed. Risoprint Cluj-Napoca, 52-105 p.

Walker G (2005). Profil de la culture du chou et du broccoli au Canada. Agriculture et Agroalimentaire Canada, 47 p. 